\title{
29. Establishment of Melanoma Cell Lines in Chemically Defined Medium
}

\author{
By Kunio Iwata and Naomichi INUI \\ Section of Cell Biology and Cytogenetics, Biological Research Center, \\ The Japan Tobacco and Salt Public Corporation \\ (Communicated by Sajiro Makino, M. J. A., March 12, 1980)
}

Melanoma cells have the character of tumor cells along with the ability to synthesize melanin. Many reports have been published on regulation of melanin synthesis (Wrathall et al., 1973; Wong and Pawelek, 1973) as well as on tumorigenesis (Kreider and Schmoyer, 1975 ; Lazo et al., 1978) in melanoma cells. Most studies in vitro, however, have been on cells in media containing serum. Since serum contains many factors with unknown biological effects, the results of experiments using media containing serum may not afford the exact features of melanoma cells in relation to melanin synthesis and tumorigenicity. This paper deals mainly with the establishment of melanoma cell lines in chemically defined medium with particular reference to the effects of Fetuin, a fetal bovine serum glycoprotein, on cell growth, with notes on chromosome numbers and melanin contents of the cells in medium with and without serum. Tumorigenicity is a subject to be reported in another paper.

Materials and methods. A melanoma cell line of B16 mouse melanoma was kindly supplied by Dr. F. Hu (Oregon Regional Primate Research Center, Oregon, U.S.A.). Two subclones derived from B16, named G4 and H9, were used in this study. They had been routinely cultured in Eagle's minimum essential medium (MEM, Nissui Seiyaku, Tokyo) supplemented with $10 \%$ fetal bovine serum (FBS, Flow Lab., Stanmore, N.S.W., Australia).

The best condition for cell growth in serum-free medium was determined by the growth and viability of these two clones after culture in MEM, Dulbecco modified MEM (DMEM), MEM $\alpha$, Waymouth's MB752/1 and Ham's F12 media without serum for three days. The survival rate was highest in DMEM and MEM $\alpha$ media, and therefore a chemically defined medium was prepared by modification of these two media. This medium contained methylcellulose 15 (Nakarai Chemical Ltd., Kyoto), eight nucleosides and N-2-hydroxyethylpiperazine-N'-2ethansulfonic acid (HEPES, Sigma Chem., St. Louis, U.S.A.) as a

Address: Biological Research Center, The Japan Tobacco and Salt Public Corporation, 23 Nakogi, Hatano, Kanagawa 257, Japan. 
buffer. The components of this medium, named J-1, are shown in Table I.

Table I. Components of J-1 medium*

\begin{tabular}{|c|c|c|c|}
\hline \multicolumn{2}{|l|}{ Inorganic salts: $(\mathrm{mg} / \mathrm{l})$} & \multicolumn{2}{|l|}{ Vitamins: $(\mathrm{mg} / \mathrm{l})$} \\
\hline $\mathrm{CuSO}_{4} 5 \mathrm{H}_{2} \mathrm{O}$ & 0.00125 & L-Ascorbic acid & 50.00 \\
\hline $\mathrm{FeSO}_{4} 7 \mathrm{H}_{2} \mathrm{O}$ & 0.417 & Biotin & 0.10 \\
\hline $\mathrm{NaHCO}_{3}$ & 1000.00 & D-Ca pantothenate & 4.00 \\
\hline $\mathrm{ZnSO}_{4} 7 \mathrm{H}_{2} \mathrm{O}$ & 0.0144 & Choline chloride & 14.00 \\
\hline \multirow{2}{*}{\multicolumn{2}{|c|}{ Amino acids: $(\mathrm{mg} / \mathrm{l})$}} & Folic acid & 4.00 \\
\hline & & i-Inositol & 18.00 \\
\hline L-Alanine & 25.00 & Nicotinamide & 4.00 \\
\hline L-Arginine $\mathrm{HCl}$ & 126.69 & Pyridoxal $\mathrm{HCl}$ & 4.00 \\
\hline L-Asparagine $\mathrm{H}_{2} \mathrm{O}$ & 50.00 & Riboflavin & 0.40 \\
\hline L-Aspartic acid & 30.00 & Thiamine $\mathrm{HCl}$ & 4.00 \\
\hline L-Cystine & 48.00 & Vitamin B12 & 1.36 \\
\hline L-Cysteine $\mathrm{HCl} \mathrm{H}_{2} \mathrm{O}$ & 100.00 & \multirow{2}{*}{\multicolumn{2}{|c|}{ Nucleosides: (mg/l) }} \\
\hline L-Glutamic acid & 75.00 & & \\
\hline L-Glutamine & 584.00 & Adenosine & 10.00 \\
\hline Glycine $\mathrm{HCl}$ & 72.47 & Cytidine & 10.00 \\
\hline L-Isoleucine & 105.00 & Guanosine & 10.00 \\
\hline L-Leucine & 105.00 & Uridine & 10.00 \\
\hline L-Methionine & 30.00 & 2'Deoxyadenosine & 10.00 \\
\hline L-Phenylalanine & 66.00 & 2'Deoxycytidine $\mathrm{HCl}$ & 11.00 \\
\hline L-Proline & 40.00 & 2'Deoxyguanosine & 10.00 \\
\hline L-Serine & 42.00 & 2'Deoxythymidine & 10.00 \\
\hline L-Threonine & 95.00 & \multicolumn{2}{|l|}{ Other components: $(\mathrm{mg} / \mathrm{l})$} \\
\hline L-Tryptophan & 16.00 & HEPES & $15 \mathrm{mM}$ \\
\hline \multirow[t]{3}{*}{ L-Valine } & 94.00 & $\begin{array}{l}\text { HEPES } \\
\text { Lipoic acid }\end{array}$ & 0.20 \\
\hline & & Methylcellulose & 1000.00 \\
\hline & & Sodium pyruvate & 110.00 \\
\hline
\end{tabular}

* The concentration of $\mathrm{CaCl}_{2}, \mathrm{KCl}, \mathrm{MgSO}_{4}, \mathrm{NaCl}, \mathrm{NaH}_{2} \mathrm{PO}_{4}$, glucose, phenol red, L-histidine, L-lysine and L-tyrosine were the same as MEM.

For passage in serum-free medium, cells were harvested by treatment with $0.25 \%$ trypsin (Difco Lab., Detroit, U.S.A.) in $\mathrm{Ca}^{++}$and $\mathrm{Mg}^{++}$free Hanks' solution at room temperature and the action of trypsin was stopped with Hanks' solution containing $400 \mu \mathrm{g} / \mathrm{ml}$ ovomucoid trypsin inhibitor (Type II-0, Sigma). The cells were then washed once or twice with J-1 medium and suspended in J-1 medium supplemented with $200 \mu \mathrm{g} / \mathrm{ml}$ Fetuin (Type III, Sigma). The cells were grown in $25 \mathrm{~cm}^{2}$ plastic flasks (Falcon Plastic, Oxnard, Calif., U.S.A.) at $37^{\circ} \mathrm{C}$ in $95 \%$ air and $5 \% \mathrm{CO}_{2}$. For maintenance of the cells, the medium was changed every two or three days, and the cells were subcultured every 7 to 8 days by 10 to 20 splits. Hereafter the G4 and H9 ctone cells which were cultivated in serum-free medium are named G4F and $\mathrm{H} 9 \mathrm{~F}$, respectively. G4F and $\mathrm{H} 9 \mathrm{~F}$ clone cells at the 18 th to 25th passage generations were used in this study. 
To determine the stretching effect of Fetuin on cells, $5 \times 10^{4}$ cells were inoculated into $3.5 \mathrm{~cm}$ plastic dishes (Falcon) with $\mathrm{J}-1$ medium containing various concentrations of Fetuin and $24 \mathrm{hrs}$ later the stretched cells were counted under a phase-contrast microscope.

For study of the effect of Fetuin on the growth of melanoma cells, 2 to $3 \times 10^{4}$ cells were also seeded onto $3.5 \mathrm{~cm}$ plastic dishes in $2 \mathrm{ml}$ of J-1 medium containing various concentrations of Fetuin. The medium was changed every two days, and 8 days later the cell number was counted with a hemocytometer. The melanin content of cells in the stationary phase was measured by the method of Whittaker (1963), and was expressed as the optical density (OD) at $400 \mathrm{~nm}$ per $10^{6}$ cells.

The chromosomes in cells under growth phase were studied after treatment with $0.3 \mu \mathrm{g} / \mathrm{ml}$ colcemid (GIBCO) for $3 \mathrm{hrs}$, being use of the routine air-drying Giemsa method.

Results and remarks. G4 clone cells were larger, and contained more melanin (Fig. 1a, arrows) than H9 clone cells (Fig. 1b). H9 clone cells were obtained by recultivation of a solid tumor of G4 clone cells, which have been successively transplanted for over three years in C57BL/6 mice. Morphologically, H9 clone cells were small, and low in melanin production, growing with an island formation.

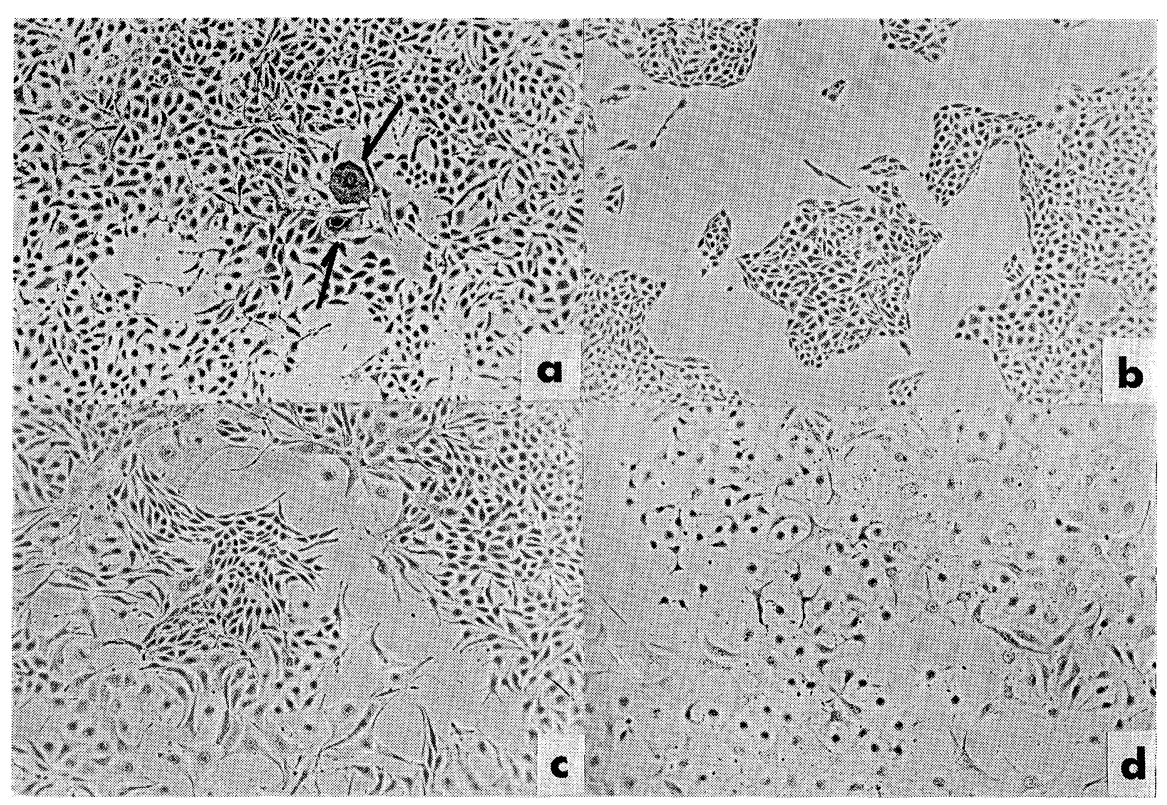

Fig. 1. Cell morphologies of the original cells and the cells in serum-free medium. a: Original G4 clone cells. b: Original H9 clone cells. c: G4F clone cells at the 20 th passage. $d$ : H9F clone cells at the 20th passage.

It was shown that both G4 and H9 clone cells in serum-free medi- 
um stretched well under a high concentration of Fetuin (Fig. 2, a, b). These cells were stretched over $90 \%$ in J-1 medium supplemented with $100 \mu \mathrm{g} / \mathrm{ml}$ Fetuin. Their Fetuin-dependency has continued for over 20 passage generations since transfer to serum-free culture.

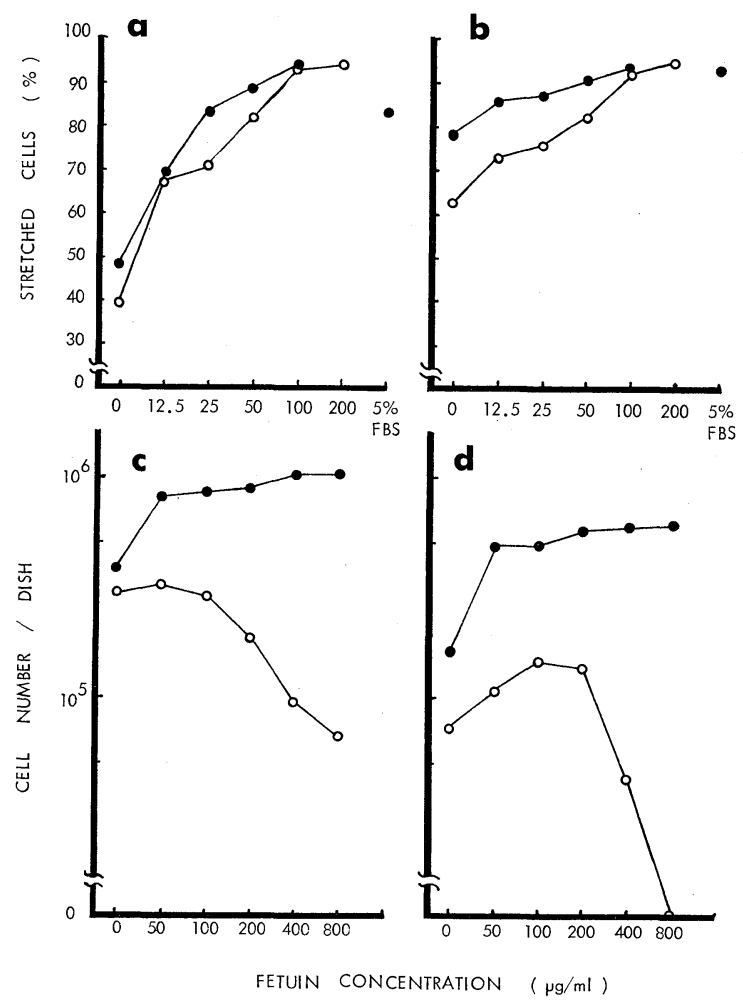

Fig. 2. Showing stretching and growth of melanoma cells under the effect of Fetuin in serum-free medium. a: Cell stretching of G4 and G4F clone cells. b: Cell stretching of $\mathrm{H} 9$ and $\mathrm{H} 9 \mathrm{~F}$ clone cells. c: Growth of G4 and G4F clone cells. d: Growth of $\mathrm{H} 9$ and $\mathrm{H} 9 \mathrm{~F}$ clone cells. $\mathrm{O}-\mathrm{O}, \mathrm{G} 4$ and H9; $\bullet-\mathrm{G} 4 \mathrm{~F}$ and $\mathrm{H} 9 \mathrm{~F}$.

Evidence was presented that Fetuin was not very effective for growth of G4 clone cells in the first culture generation, compared with growth of $\mathrm{H} 9$ clone cells (Fig. 2, c, d). H9 clone cells required 100 to $200 \mu \mathrm{g} / \mathrm{ml}$ of Fetuin for maximal growth, though $800 \mu \mathrm{g} / \mathrm{ml}$ of Fetuin was very toxic. Referring to these results, $200 \mu \mathrm{g} / \mathrm{ml}$ Fetuin was used for cultivation. After the 20th passage generation in J-1 medium without serum, G4F and $\mathrm{H} 9 \mathrm{~F}$ clone cells grew well with a higher concentration of Fetuin. This change of cell growth to Fetuin-dependency may probably be due to adaptation of the cells to Fetuin. Puck et al. (1968) reported that Fetuin was effective for promoting attachment and stretching of HeLa cells in culture and for a high plating efficiency. 
The doubling time of G4 clone cells in the primary phase in serumfree medium with $50 \mu \mathrm{g} / \mathrm{ml}$ of Fetuin (the most effective concentration for growth; Fig. 2a) was nearly $40 \mathrm{hrs}$, while $30 \mathrm{hrs}$ in the 20 th passage culture (G4F). The saturation density of G4F clone cells has been maintained at almost the same value $\left(2.4 \times 10^{6} / 3.5 \mathrm{~cm}\right.$ dish $)$ for 20 passage generations in serum-free medium. H9 clone cells in J-1 medium containing $200 \mu \mathrm{g} / \mathrm{ml}$ of Fetuin at the first generation grew slowly and their doubling time was over $60 \mathrm{hrs}$, whereas about $25 \mathrm{hrs}$ in the presence of $10 \%$ FBS. After 20 passage generations, however, the doubling time of $\mathrm{H} 9 \mathrm{~F}$ clone cells was $33 \mathrm{hrs}$ in serum-free medium. The saturation density of $\mathrm{H} 9 \mathrm{~F}$ clone cells in both serum-free medium and medium with $10 \%$ FBS $\left(1.8 \times 10^{6} / 3.5 \mathrm{~cm}\right.$ dish $)$ was one-third less than that of the original $\mathrm{H} 9$ clone cells $\left(5.4 \times 10^{6} / 3.5 \mathrm{~cm}\right.$ dish $)$. This feature may be due to the enlargement of the cells with the increase in their volume (Fig. 1d).

The melanin contents of G4F and H9F clone cells in the stationary phase are as follows: G4 clone cells had a high melanin content in MEIM supplemented with $10 \%$ FBS, but decreased during cultures in serum-free medium $\left(\mathrm{G} 4 \mathrm{~F} ; \mathrm{OD}_{400} \mathrm{~nm} / 10^{6}\right.$ cells=0.0425). When $\mathrm{G} 4 \mathrm{~F}$ clone cells were treated with $10 \% \mathrm{FBS}$, their melanin content $\left(\mathrm{OD}_{400}\right.$ $\mathrm{nm} / 10^{6}$ cells $=0.1158$ ) increased to almost the same values as that of G4 clone cells in MEM supplemented with $10 \%$ FBS. These findings suggest that serum contains some factor that stimulates melanin synthesis. The melanin contents of H9F clone cells, however, remained unchanged in the absence and presence of $10 \% \mathrm{FBS}\left(\mathrm{OD}_{400} \mathrm{~nm} / 10^{6}\right.$ cells $=0.0542$ without FBS ; 0.0539 with $10 \%$ FBS) .

The chromosome numbers of both $\mathrm{G} 4$ and $\mathrm{G} 4 \mathrm{~F}$ clone cells ranged from 70 to 90 with a mode at 79 . Those of the original H9 clone cells were between 40 to 50 (mode, 48), while H9F clone cells had 80 to 100 chromosomes at the 21 st passage generation (mode, 80 ). Interesting is the fact that the two melanoma cell lines showed near tetraploidy in serum-free medium, suggesting that tetraploid cells favorably grow in serum-free medium.

When G4F and H9F clone cells were transferred back to medium containing FBS, the G4F clone cells changed into the original shape, whereas the H9F clone cells showed no change (data not shown).

Then the conclusion is possible that during cultivation in serumfree medium G4F clone cells did not change in character, whereas $\mathrm{H} 9 \mathrm{~F}$ clone cells showed remarkable change. In this work, fine, successful cultures of melanoma cells were availably made in serum-free, chemically defined medium. At present, the cultures have been continuing for over 70 passage generations. These two clones in serum-free medium may be subjects useful for assessment of the regulation of melanin synthesis. 
Acknowledgement. We are very grateful to Dr. Takuji Takeuchi, Tohoku University for continuous advice and encouragement.

\section{References}

Kreider, J. W., and Schmoyer, M. E. (1975) : J. Natl. Cancer Inst., 55, 641-647. Lazo, J. S., Ingber, D. E., and Sartorelli, A. C. (1978) : Cancer Res., 38, 22632270.

Puck, T. T., Waldren, C. A., and Jones, C. (1968) : Proc. Natl. Acad. Sci., U.S.A., 59, 192-199.

Whittaker, J. R. (1963) : Dev. Biol., 8, 99-127.

Wong, G., and Pawelek, J. (1973) : Nature New Biology, 241, 213-215.

Wrathall, J. R., Oliver, C., Silagi, S., and Essner, E. (1973) : J. Cell Biol., 57, 406-423. 